\title{
Market Competition, Public Good, and State Interference
}

\author{
ALBERTO AMARAL AND ANTÓNIO MAGALHÃES
}

\section{Introduction}

Over the last decades the relationship between higher education institutions and the state has changed from a model of state control to a model of state supervision. Simply put, this new model implies that institutions are given some degree of autonomy; that they self-regulate their behaviour in response to distant steering from the government. However, governments began increasingly to interfere in higher education creating what has been called the 'interventionary' state or even the 'evaluative' state.

More recently, at least in some countries, neo-liberal governments have come into power and a new political rhetoric has become popular. Neo-liberal politicians proclaim that the state should decrease its activity as service provider, that state regulation should retreat in favour of market regulation, and that competition is a necessary ingredient to ensure that institutions become more responsive to society and more efficient in the use of public funds.

This new model was expected to soften state interference in higher education institutions. However, when autonomous institutions are forced to compete under market-like conditions, they might follow strategies aiming at increasing 'their own good'. This does not guarantee that the strategic objectives defined by the institutions will coincide or converge with the 'public good' or the government's objectives, which opens the way for even more state interference. 
This paper analyses data from Portugal and the UK to argue that autonomous institutions in a competitive environment may develop strategies to ensure institutional advantages that may be contrary to governmental policy objectives. This opens the way to corrective action from the state and creates a paradoxical situation where, despite a current neo-liberal rhetoric of "less state" there is actually increasing state interference in public services.

\section{Changing relationship between higher education institutions and the state}

In recent decades the relationship between higher education institutions and the state has undergone major transformations away from the model of state control characteristic of the early stages of the modern university. The "facilitatory state" described by Neave and Van Vught (1991, p. xi), was the form the state assumed to manage the social demand for higher education after World War II until the end of the 1960s. This period corresponds to a change from a 'primary' welfare state "designed to provide a safety net for the poor" to a 'secondary' welfare state which mobilised institutions (including universities) "to promote a democratic culture and to encourage social mobility" (Scott 1995, p. 79).

In Western Europe, the instability of the 1960s was mainly felt at the institutional level. Faced with an instability that had worked its way out of academia to become a pervasive political concern, governments elected to act within the sphere of the 'private life' (Trow 1996) of the universities, thus reducing a social uprising to a case of students' unrest. Government reforms to normalise the 'private life' of academia by mandating its organisational characteristics (patterns of participation, governance, and authority) announced a different, 'interventionary' posture of the state.

From about 1983-85, governments began to interfere even more in higher education, radicalising the 'interventionary' state. This coincided with the emergence of "a more elaborate 'secondary' welfare state with a more active and interventionist agenda" (Scott 1995, p. 79).

In Prometheus Bound (1991), Neave and Van Vught suggested that something was changing, "Hercules is on his way" to unchain Prometheus, and that a new sort of relationship was emerging through a hybrid composition of state regulation and claims of institutional autonomy; leading to what they have called a model of "state supervision". In the new model the state abandons its traditional strategy of "rational planning and control' in favour of 'self-regulation' (Van Vught 1989). How- 
ever, Neave and Van Vught (1991) have warned of the danger that under increasing product control by the government, the academe might be "gradually reduced to the status of a 'knowledge factory' - impotent to resist the short-term and political opportunism of objectives which government has set" (Neave and Van Vught 1991, p. 253) and have recognised that "...the musicians are still marching down the broad highway of detailed plan and control" (Neave and Van Vught 1991).

\section{Neo-liberalism, privatisation, and competition - the promising Hercules?}

In some countries, neo-liberal governments have recently come into power and introduced a new political rhetoric. Increased privatisation of higher education has been observed under a variety of forms, which include the establishment of private higher education institutions, the use of market mechanisms, and the increased contribution of students and families to the costs of higher education.

The 'market' has emerged at the centre of the political stage at two different levels. At one level it has emerged as a reality that social systems couldn't afford to neglect if they intend to survive; at another level as a rhetorical device to legitimate policies. Neave states that in Western Europe the orientation towards market (de)regulation - at least as far as higher education is concerned - was a pragmatic answer to the need to transfer resources to other welfare areas such as health and social security, rather than an option determined by the inner virtues of the market as a regulation instance (Neave 1995, pp. 57-58). Yet, the 'market' also appears as the ideological building block of the rising mode of regulation, especially when one refers to the US example where this development "[...] stands foursquare in current debate [...] over the place and responsibility of government" (Neave 1995, p. 59).

Jongbloed (2004, pp. 89-90) uses a traffic metaphor to clarify the differences between the traditional government system of centralised command and control (similar to traffic signals) to coordinate their higher education systems and the adoption of market-based policies (similar to a roundabout). In Jongbloed's metaphor, traffic lights heavily condition drivers' decisions, the same way government regulation conditions the behaviour of institutions. On the other hand, while influencing traffic behaviour, a roundabout delegates decision-making authority to the drivers (Dill et al. 2004, p. 329).

Militant neo-liberal politicians proclaim that the state should decrease its activity as service provider, that state regulation should retreat 
in favour of market regulation, and that competition among institutions is a necessary ingredient to ensure that institutions become more responsive to society and more efficient in the use of public funds.

Does all this mean that the market will emerge as the new Hercules coming to unchain Prometheus? Will it succeed? Can autonomous universities be trusted to pursue the public good even under market competition or, on the contrary, will the state have to intervene in more detail to ensure that universities do not deviate from their public service obligations?

In two very interesting papers Massy $(2004 a, b)$ argues that “...the way institutions currently respond to markets and seek internal efficiencies, left unchecked, is unlikely to serve the public good" (Massy 2004b, p. 28), a danger exacerbated by excessive competition or by retrenchment operations. Massy (2004b) argues that when competition is excessive or when the state cuts public subsidies that curtail the institutional capacity for discretionary spending, non-profit institutions behave as for-profit ones, ignoring the promotion of the public good inherent to their missions. This forces the state to intervene by changing the rules of the market to ensure the fulfilment of its own political objectives.

Public universities receive at least a significant part of their budgets from the state under the argument that they further the public good by contributing to economic development and advancing the life prospects of citizens through increasing their 'employability' potential (to use the new European terminology). Public universities are non-profit organisations that are forced by law to reinvest any surplus in the organisation itself instead of ending-up in private benefits for its members. In principle this offers the state some guarantee that the organisation will not digress from its obligation of upholding the public good. And it explains why the state, at least in most European countries, mistrusts private higher education institutions and either forbids them or tries to control them more closely that it does for public institutions (Teixeira and Amaral 2001).

This paper analyses the behaviour of non-profit higher education institutions in a market-like competitive environment to understand if they will always uphold the primacy of the public good or if will they promote their own 'private good', namely under conditions of financial stringency or exacerbated competition, thus justifying a more interventionist role for the government. 


\section{Two European cases, Portugal and the UK}

To address the thesis that non-profit institutions may develop strategies that do not converge with government policy objectives or the public good, we have studied two cases, the UK and Portugal. The UK was chosen because it is the most extreme example among European countries of the emergence of neo-liberal policies; including the emergence of new managerialism in public administration, the appointment of nonacademic vice-chancellors and presidents, increased accountability, and promotion of inter-institutional competition. Portugal was chosen as a good example of a 'weak state' unable to properly steer the system, where a large private sector of higher education institutions (non-profit in principle) was allowed to develop alongside the public sector.

\subsection{The case of the UK}

We used the UK White Paper on Higher Education (Dfes 2003a) - The Future of Higher Education to select two policies the Government defined as high priority:

"Fair access: Universities are a vital gateway to opportunity and fulfilment for young people, so it is crucial that they continue to make real and sustained improvements in access. The social class gap among those entering higher education is unacceptably wide. Those from the top three social classes are almost three times as likely to enter higher education as those from the bottom three. ...Young people from professional backgrounds are over." (Dfes 2003a, p. 17)

"Research: The Government intends to improve the position of research further by focusing resources more effectively on the best research performers... Concentration brings real benefits, including better infrastructure (funding excellent equipment and good libraries), better opportunities for interdisciplinary research, and the benefits for both staff and students, which flow from discussing their research and collaborating in projects." (Dfes 2003, p. 28)

“...Taken together with the exceptionally generous funding settlement for research, these proposals will reinforce the position of our leading institutions so that they can continue to compete on the world stage..." (Dfes 2003, p. 38)

Fair access has received considerable attention from the Government because the proclaimed intention of widening access might be seen as incongruent with the decision to increase tuition fees by allowing universities to set their value between a minimum of $£ 1,000$ and a maximum of $£ 3,000$. Following the 2003 White Paper, the Department for 
Education and Skills (Dfes) produced a paper on "Widening participation in higher education" (Dfes 2003b) and commissioned a report from the Admissions to Higher Education Steering Group (AHESG) on good admission practices that was published in September 2004 (AHESG 2004). The 2004 Higher Education Act has received Royal assent on 1 July 2004 and makes provisions for the establishment of an Office for Fair Access (OFFA).

Both the "widening participation" paper and the commissioned report have recognised a considerable gap between the participation of young people from families working in occupations classified as skilled (manual), partly skilled or unskilled (IIIM, IV, and V social class groups) and the participation of young people from families with professional and non-manual occupations (I, II, and IIN social class groups). While participation of the former groups increased from $10 \%$ to $18 \%$ during 1990-2000, the participation of the latter groups increased from $37 \%$ to $48 \%$. Therefore, despite the massification of the higher education system, the gap in participation between young people from higher and lower social class backgrounds has increased.

The Dfes considers the principal cause for the increasing gap the big discrepancy in attainment as "for example only $19 \%$ of those manual backgrounds obtain tow or more A-levels by the age of 18 compared to $43 \%$ from non-manual backgrounds" (Dfes 2003b, p. 7). Other causes are differences in aspiration ("one in four working class young people who achieve eight good GSCE passes do not end up in higher education" Dfes 2003b, p. 2) and differences in application (a significant number of well-qualified students, namely those from the state sector, do not apply to universities where competition for places is high, a behaviour that contrasts with that of students from independent schools).

Admissions to higher education are considered a matter for universities, not for the government (Dfes 2003, p. 2, p. 15). However, despite maintaining that admission to the university must be on merit, and irrespective of class or school attended, the Dfes has questioned the traditional admission criteria based on the A level system by considering that "prior attainment, as measured by examination and assessment results [the number of A levels], does not necessarily provide a complete guide to the potential of a student to succeed in higher education" (Dfes 2003b, p. 16).

The AHESG report (2004) has supported the position of the Dfes by defining a fair admissions system as one providing "equal opportunity for all individuals, regardless of background, to gain admission to a course suited to their ability and aspirations" (AHESG report 2004, p. 6) and suggesting that "merit could mean admitting applicants with the 
highest examination marks, or it could mean taking a wider view about each applicant's achievements and potential" (AHESG report 2004, p. $6)$.

In other words, as prior attainment is considered the main barrier to decreasing the participation gap between students from lower and higher social class groups, universities were asked to rely less on the traditional A level system by taking into account that "it is fair and appropriate to consider contextual factors as well as formal educational achievement, given the variation in learners' opportunities and circumstances" (AHESG report 2004, p. 6).

Although higher education institutions can introduce variable tuition fees of up to $£ 3,000$ per year from 2006 , the Dfes (2003b, p. 18) has stressed, "the Government is determined to ensure that access to higher education is broadened not narrowed" and it has created the OFFA to fulfil this objective "to exercise judgements in ensuring that universities are taking the actions they see as necessary to achieve their widening participation ambitions if they introduce variable tuition fees" (Dfes 2003b, p. 21).

Despite the government's clear intention of widening participation, it is not clear that all universities will align institutional strategies with this objective. The PA Consulting Group has published a report The Survival of the Fittest (2004) on the degree of alignment between the policy objectives set out by the Government and the business priorities driving institutional decisions. This report is based on the results of a survey of all heads of the UK's more than 170 autonomous universities and other higher education institutions. The survey collects the views and expectations of the vice-chancellors on the future direction of higher education and what "they perceive to be in the best interests of their institution in an increasingly competitive market for students, contracts and funding" (The Survival of the Fittest 2004, p. 3).

Some universities will tend to increasingly avoid recruiting students from poor backgrounds funded by the Higher Education Funding Council of England (HEFCE) as they consider that it does not make good business sense, preferring instead to reinforce their activities in the areas of post-graduate, professional development, and non-European international provision, which offer better business prospects. The PA Consulting report transcribes comments from respondents to their survey that articulate that trend:

"Eventually we expect to have a different profile and mix based on more postgraduates and fewer undergraduates, more professional and NHS, and more international students. We have agreed a major change programme to . . .shift 
the balance of activity, reducing dependency on HEFCE funded with growth achieved (income) from new markets." (PA Consulting 2004, p. 15).

The attitude against wider participation was reinforced by a report (JM Consulting 2004) commissioned by the HEFCE, Universities UK (UUK), and the Standing Conference of Principals (SCOP), on the costs of widening participation (WP). Based on data from 18 institutional case studies the report concluded that the average costs of WP students are $131 \%$ of a Band D student (i.e., one studying a standard classroombased subject) to be compared against a funding allocation of $118 \%$ of the base price in $2003 / 04$. It is suggested that:

“...many HEIs are absorbing a range of 'hidden' costs associated with widening participation activities, in areas including academic staff, support staff (e.g. finance, counselling), and the use of facilities. As institutions become more aware of their costs and their cost drivers these might become more visible..." (JM Consulting 2004, p. 30).

It is in this context that the government has established the OFFA and mandatory "access agreements" to be approved by the OFFA for all universities wishing to charge variable fees in excess of the standard fee (currently $£ 1,000$ ). These agreements will cover "an institution's plans for outreach, financial and other support for students and its own milestones for assessing progress in widening participation" (Dfes 2003b, p. 19).

The second area of government intervention relates to research policy and the idea that resources should be concentrated in a small number of centres of excellence rather than dispersed throughout the higher education system. This policy has been implemented since the unification of the system but the 2003 White Paper proposes to reinforce its implementation, paving the way to 'teaching-only' institutions.

In a statement to the Commons, Education and Skills Secretary Charles Clark, (22 January 2003) argued that "we need still more focus upon world-class research" and has made clear that the government's policy "means giving extra resources to our very best research departments and world class universities as well as ensuring new research will emerge and flourish". This concentration of research financing in a small number of institutions was combined with a proposal for awarding the title of university to "teaching-only" institutions. However, this was rejected by universities as a threat to the traditional relationship between education and research inherited from the idea of the Humboldtian University. The March 2004 Consultation Report by the Dfes (2004b), 
showed that analysis of responses to the consultation on proposed new criteria for degree awarding powers and university title concluded:

"There were mixed views on the proposal to allow institutions with only taught degree awarding powers (DAP) to be eligible for university title (UT) in future. Universities UK and individual universities generally opposed the proposal with the Standing Committee of Principals (SCOP) and other higher education institutions (HEIs) in support." (Dfes 2004, p. 2)

However, in the comments to the responses on the 2003 White Paper public consultation, the Ministry argued that excellent teaching can take place where teachers are not engaged in publicly funded research (DFES 2004a). In May 2004 the Dfes produced a new discussion paper, Renewable Degree Awarding Powers (Dfes 2004c), proposing that instead of maintaining the practice of granting degree awarding powers (DAP) on an indefinite basis, "DAP should in future be granted for fixed terms, renewable subject to satisfactory external audit". The analysis of responses to the consultation (Dfeds 2004d) concluded that "there was an overwhelming response in favour of organisations in the publicly-funded higher education sector gaining indefinite DAP while other organisations have fixed term DAP".

On 16 July 2004 Higher Education Minister Alan Johnson made a statement to the House of Commons announcing his decision to grant the university title on the basis of taught degree awarding powers and number of students, thus allowing institutions without research degree awarding powers to gain the title. This means that the Government was not receptive to widespread public opposition, and was committed to implement its policy of concentrating research funding even at the expense of decoupling teaching and research.

In August 2004, the Dfes issued the "Guidance for applicant organisations in England and Wales" (Dfes 2004e) including provisions for an organisation applying for the title of University provided that it must:

- have been granted powers to award taught degrees;

- normally have at least 4,000 full time equivalent higher education students, of whom at least 3,000 are registered on degree level courses (including foundation degree programmes); and,

- be able to demonstrate that it has regard to the principles of good governance as are relevant to its sector.

Despite this clear policy of concentration of research resources in a small number of research institutions, and the establishment of "teach- 
ing-only" institutions, the survey of the PA Consulting reveals that "most universities continue to regard their research strengths in particular areas as an important competitive differentiator, and are planning to increase their investment in selected research areas" $(2004$, p. 19) thus opposing the objectives of government policy.

This shows that the myth of the Humboldtian university still persists not only in academia but also in society, ignoring Habermas' proposition (1987, p. 41) that "the assertion of un-broken faithfulness to Humboldt is the life-lie of too many of our present day European universities and academics". Lindsay and Rogers (1998) argue that students tend to make decisions in terms of an institution's reputation, which is determined mainly by the institution's research reputation rather than the quality of teaching. And this might explain why university managers think that giving the institution a research profile is still good business, even if funds need to be raised from sources alternative to public funding.

\subsection{The case of Portugal}

We have used data collected in our research projects for the Portuguese case. In Portugal the awareness of the economic value of education slowly permeated the political jargon during the 1960s as the authorities assumed there was a connexion between the supply of skilled labour and the rate of economic growth. This was a major consequence of Portugal's participation in the OECD (then the OEEC) Mediterranean Regional Project (MRP) together with Italy, Greece, Spain, and Yugoslavia. The MRP was the first large-scale international educational planning exercise, and created a scenario where the capacity building of human resources played a major role in economic policy. In the early 1970s these political changes materialised in the expansion of the higher education system, including initial steps in the implementation of a binary system.

After the 1974 Revolution the importance of education in economic policy remained unchallenged. The 1975 Government Action Programme recognised that: "Educational policy has its place in this Programme of Social and Economic Policy as one of the fundamental tools for promoting economic development..." (Programa do Governo Provisório 1975, pp. 9-10). The World Bank strongly supported this political orientation. From 1978 to 1984, the Bank sent 19 Missions of Supervision to Portugal to provide technical assistance. These missions have had a significant impact on educational policies that reflected the Bank's strong views on direct links between higher education and the needs of 
the economy (Teixeira et al. 2003). These views are repeated over and over in the World Bank's reports for the Portuguese government:

“....an investigation linked to manpower requirements, needs to be undertaken in the higher education system with a view not only to determining the nature and areas of specialisations required for economic development of the country ...” (World Bank 1977, p. 14)

“...rationalising educational development in accordance with plans for economic development and manpower needs, particularly in reference to secondary and tertiary levels." (World Bank 1977, p. i)

“...rationalising educational development at the secondary and tertiary levels in accordance with the country's economic plans, manpower requirements, and available resources." (World Bank 1977, p. ii)

But the Bank also provided support for the introduction of a generalised system of numerus clausus to contain the fast expansion of enrolments observed after the 1974 Revolution - enrolments jumped by almost onethird in three years: "In view of the rapidly increased university enrolments, which represent an uneconomical drain in the economy...[the Bank recommends a] gradual introduction of quantitative restraints..." (World Bank 1977, p. ii). The Bank has also been in favour of the implementation of vocationally oriented institutions (polytechnics) offering shorter degrees than the university sub-system. However, without reducing the supply of university graduates, particularly in engineering, graduates from the polytechnics might find employment opportunities scarce; the Bank saw this as a threat to the new short vocational education programmes.

The investments in the non-university education system, given priority over the higher education system, produced an increasing number of candidates to higher education, which combined with the limits to access to higher education set by the numeri clausi created an increasing mismatch between the number of candidates and the number of vacancies. By the mid-1980s the situation had become intolerable as a large number of young people were left outside higher education without any credible alternative. This context promoted the emergence of private non-profit higher education institutions, which have developed quickly under the political patronage of Minister of Education Roberto Carneiro (1987-1991), an indefatigable champion of the private sector.

There has been strong support at the political discourse level for a much more prominent role for private higher education, clearly assumed by leading political actors as an important ideological instrument for 
strengthening Portuguese democracy, and as a tool for its social and economic development. On the other hand, the lack of public resources and a climate of financial stringency have paved the way for the development of the private sector as it contributed to increase student enrolment without additional demands on the public budget.

At the time of the revolution the supply of private higher education was basically restricted to the Portuguese Catholic University. Minister Vitor Crespo (1980-1982) allowed for the establishment of the first private university and Minister Deus Pinheiro (1985-1987) authorised an additional significant number of private institutions. However, the consolidation and expansion of the private sector is associated in general with Minister Roberto Carneiro (1987-1991) who did not hide his ideological belief in the private sector. In 1989 Carneiro created very favourable conditions for expansion of the private sector by eliminating minimum passing marks on entrance examinations to higher education; almost doubling demand from one day to the next. Students have been allowed to enter higher education even with zero marks in the entrance examinations, which has only become a tool for ranking students in the national competition for vacancies. This has created a huge market for the expansion of the private sector without close scrutiny of the quality of educational provision.

Expansion has been very fast in terms of enrolment. In 1983/84 public enrolments represented $88.6 \%$ against $11.4 \%$ of the private sector; in $1990 / 91$ the values were $72.5 \%$ and $27.5 \%$ respectively; in $1995 / 96$ the public sector represented $63.4 \%$ against $36.6 \%$ for the private sector; in $2000 / 01$ the public sector accounted for $70.4 \%$ and the private sector for 29.65 ; and in 2003/04 the public sector had increased to $72.6 \%$ and the private sector had decreased to $27.4 \%$. These values show that after a very fast increase of the private sector its enrolments have been declining over the last few years.

Expansion of higher education and its diversification, as well as the increase of student enrolments in fields of economic importance have been explicit government policy goals for almost two decades. Minister Carneiro placed high expectations on the private sector to fulfil these goals. It was believed not only that private institutions would provide an educational provision better adapted to economic and regional demands and societal needs, but would also contribute to the diversity of the system in geographic as well as disciplinary terms (Sousa Franco 1994).

Contrary to those expectations however, the private sector developed in directions opposite to the government's objectives. Figures 1 and 2 represent the vacancies of the private and public sectors arranged by disciplinary areas (Table 1) for the period 1992/93 to 1998/99. 
Table 1: Disciplinary areas

\begin{tabular}{|l|l|l|l|}
\hline Code & Area & Code & Area \\
\hline 100 & Teacher training & 600 & Agriculture \\
\hline 200 & Arts and Humanities & 700 & Health and Social security \\
\hline 300 & $\begin{array}{l}\text { Social Sciences, } \\
\text { Commerce and Law }\end{array}$ & 800 & Services \\
\hline 400 & Sciences & 900 & Others \\
\hline 500 & $\begin{array}{l}\text { Architecture and } \\
\text { Engineering }\end{array}$ & & \\
\hline
\end{tabular}

It is obvious that the private sector (Figure 1) concentrates its offer mainly in area 300 (Social Sciences, Commerce and Law), 47.8\% of the total offer, almost ignoring the areas 400 (Sciences) and 500 (Architecture and Engineering) in opposition to the government declared priorities. In the public sector (Figure 2) the distribution across disciplines is more balanced, with area 300 only $28.4 \%$ of the total offer against $35.8 \%$ of the combined areas 400 and 500 .

Figure 1: Vacancies in private institutions by disciplinary areas (92/93 to $98 / 99$ )

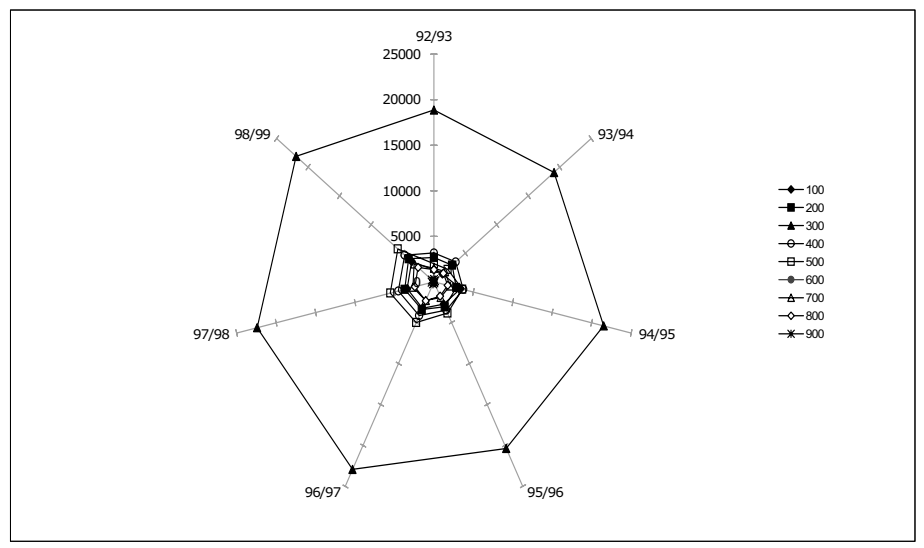


Figure 2: Vacancies in public institutions by disciplinary areas (92/93 to $98 / 99$ )

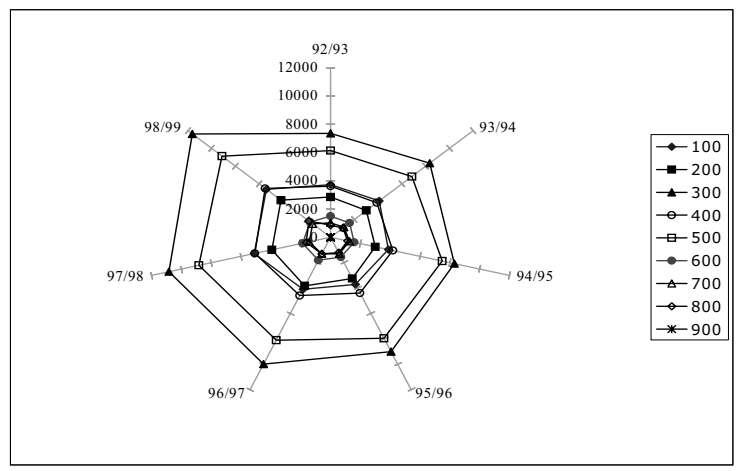

The contribution of the private sector has also not fulfilled political expectations that it would contribute to better regional distribution of higher education institutions throughout Portugal, i.e., to more equitable regional diversity. Figure 3 shows that private HEIs have concentrated mainly in the most populated areas of the districts of Lisbon (and Setúbal) - in the Lisbon and Tagus Valley Region - and Porto - in the North Region - where available vacancies largely exceed those offered by the public sector. "Indeed, the element of profit present in the market's logic explains why private institutions avoid less developed regions or regions with lower population density" (Correia et al. 2002 p. 110).

Figure 3: Regional distribution of vacancies - private sector

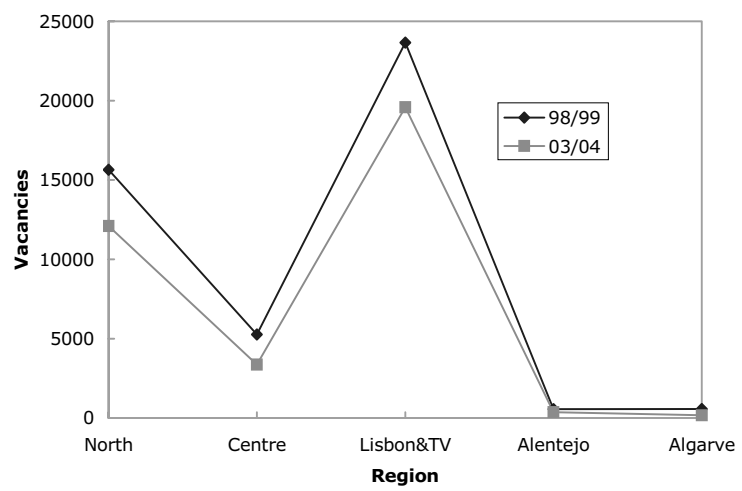


This development of the private HE sector has been criticised by the World Bank. In its 1989 report the Bank considered that the Portuguese government still lacked a policy on private higher education institutions, allowing them to increase the imbalances of the scientific and regional distribution of higher education supply (Amaral and Teixeira 2000).

These results show that the government's explicit goals of diversification and economic relevance have not been fully attained despite a rather restrictive legal framework that imposed the Ministry's authorisation before the private sector and the public polytechnics could initiate new study programmes. The government has adopted a lax regulation approach allowing both the mushrooming of the private sector in a direction contrary to the aims of the diversification policy (geographical distortions and insufficient supply of technical degrees), as well as some academic drift of the polytechnics. Despite general political statements hinting at greater disciplinary and regional diversity and increased responsiveness to economic and social demands, the government's 'laissez-faire' attitude has allowed the private sector to develop in a most uncontrolled manner, and in directions contrary to the government's objectives. For more detailed information on the impact of the private higher education sector upon the development of Portuguese education see Teixeira and Amaral (2001) and Correia et al. (2002).

The government's planning ineptitude and its permissive attitude towards the private sector has resulted in disaster. The expansion trend of demand was reversed in 1996 when the number of candidates for higher education started to decline. At the time, the gross participation rate was already over $40 \%$ of the relevant age cohort and the government shifted its attention from increasing 'quantity' to improving 'quality'. Pass examinations at the end of the tenth and eleventh grades, and national examinations for each subject at the end of the twelfth grade, have been re-established and Minister Marçal Grilo has reversed the permissive access rules set by Carneiro. Higher education institutions are allowed to set minimum marks in the access examinations to higher education, putting an end to the ludicrous situation of students to entering with zero marks. This move to improve quality has taken place at the same time that the consequences of two decades of low birth rate were beginning to affect the size of the 18-24-age cohort (Amaral and Teixeira 1999). The combined result of these two trends - raising the standards to enter higher education and decreasing the age cohort - has created a severe crisis that can force the collapse of many private institutions.

The establishment of this "market-like" competition for students will influence future developments of the Portuguese higher education sys- 
tem. Private institutions have everything to lose in this game, : they are more expensive for students, their recruitment is very local, and their social prestige is not very strong. Not only the private sector is facing a challenge however; public polytechnics, especially those located in towns where there are also well-established universities competing directly for the available students, will face increasing enrolment difficulties, as well as some of the younger public universities located in less populated inland regions. Recent legislation enforcing minimum marks in the national access exams for every candidate to higher education (public or private, universities or polytechnics) may contribute to reinforce the declining trend of enrolments.

\subsection{Comments}

The PA Consulting group report (2004) compared the objectives of the government against the intentions of Vice-Chancellors and concluded that "market responses may not deliver the collective policy goals for higher education" (PA Consulting 2004, p. 6) as "there is a paradoxical dissonance between the objectives driving government-led changes in higher education policy and the responses being pursued by vicechancellors" (PA Consulting, p. 8).

We argue that this 'paradoxical dissonance' can be easily explained by taking into account that changes of the UK higher education system have strongly relied on market-based solutions. Shattock (2003) states "financial stringency, competition, the RAE [Research Assessment Exercise] and other factors have had the effect of considerably sharpening institutional management." Therefore, universities have learned the hard way and many will no longer pursue policy goals that do not correspond to 'good business'.

The PA Consulting report is clear in the UK case in recognising that vice-chancellors look for opportunities for their institutions under the legal framework imposed by the government, which does not guarantee convergence with the government policy goals for the system (PA Consulting 2004). Some national objectives such as social inclusion or closer collaboration with local companies might not be considered sound business opportunities by institutions. PA Consulting considers this mismatch between government objectives and institutional strategies might result in increased government control and interference:

“...Government's encouragement of a competitive environment among universities is succeeding to a point, but that market outcomes may not yet fully align with all the Government's objectives. This is likely to require a more ac- 
tive role from Government in managing and influencing both the demand and supply side of the emerging market." (PA Consulting 2004, p. 21)

Vice-chancellors have strongly resented the contradiction between market-like competition and the increasingly interventionist role played by the state. One respondent stated:

"The White Paper has a contradiction at its heart: on the one hand, it vigorously promotes market forces and greater competition; on the other hand, it increases forms of central regulation, sets limits to prices, and is very prescriptive." (PA Consulting 2004, p. 8)

The vision of increasing government interference is shared by a significant number of researchers and institutions. For Tapper and Salter (2004, p. 12) increasing state intervention has been eroding institutional autonomy to force institutions to deliver outcomes in keeping with politically defined goals "over time the political control of policy direction has become both more all-encompassing and more detailed".

In its response to the 2003 White Paper the Royal Society (30 April 2003) suggested:

"... the Government needs to recognise that it is more important to have the correct governance arrangements, coupled with appropriate reporting of statistical and other output information, than to be constantly trying to steer and micromanage HEIs from the centre."

This analysis shows a developing state interference to ensure that political objectives are fulfilled, even if the government's proposals are contradictory or not consensual. For instance, the Royal Society (Tapper and Salter 2004) considered that "further significant increases to research selectivity at a departmental level would have serious detrimental consequences" and "extending the use of the title 'university' may not achieve this end [to increase the status of HEIs] and could have other undesirable consequences.

The Portuguese case is somewhat different from the UK case, as it represents a typical example of a weak state, unable to properly steer the system, resorting to "a bureaucratic weak and arbitrary form of intervention based on prescriptive fiat and rigid rules and procedures" (Kraak 2001, p. 31).

The Portuguese private sector is mainly non-profit (at least on paper) and does not receive direct public subsidies, depending for its survival on the revenues from tuition fees and other taxes paid by students. As private institutions cannot easily spare money for discretionary funding, 
they assume strong elements of for-profit behaviour (Massy 2004a), which have resulted in strategies contrary to the government's objectives. This has led the private sector to concentrate its offer in areas of low running costs and low investment - Social Sciences, Commerce, and Law - while avoiding strong involvement in areas such as Architecture and Engineering, despite the government's political decision of giving priority to these areas.

This "weak state" behaviour has also been evident in the government's lack of capacity to resist pressures to expand the system by authorising an increasing number of private institutions and study programmes. This has led the Portuguese higher education system to a deep crisis; public and private sectors have been allowed to develop without taking decreasing birth rates into account, which has created an overcapacity that will last for more than two decades. At present there are obvious signs of this crisis as some private institutions merge and others go bankrupt or are sold. Only when this crisis was evident did the state intervene, sporadically resorting to extraordinary measures that attempt to force reality to conform to the results desired by the political actors.

There are signs of the emergence of reinforced state interference in Portugal. The Law 1/2003, passed in January 2003, determines:

- the establishment of a new higher education institution requires prior accreditation - based on criteria of the expected quality of teaching, social relevance, and financial viability - by the Ministry after consulting the recently established Higher Education Council;

- the creation of new departments or faculties in existing higher education institutions follow similar procedures;

- that the pedagogical autonomy of public universities be lowered to a level close to the level of autonomy of polytechnics and the private sector;

- that a system of 'academic accreditation' be implemented by the same agencies responsible for the quality evaluation system;

- that the Ministry may use the results of accreditation to close down institutions and study programmes;

- that the Ministry may close down study programmes with low enrolments;

- that under specific circumstances, the Ministry may establish the basic curricula of the different study programmes offered at national level.

The Portuguese government has also made other political decisions that may be seen as a movement towards a market regulated system, more 
compatible with its neo-liberal inclination (Teixeira et al. 2004). But these 'pro-market' decisions have been obscured by a decisive movement towards state interference that denounces a weak state and its lack of sophistication that precludes efficient steering.

\section{Conclusions}

The two cases support the thesis that autonomous institutions may develop strategies to ensure institutional advantages even when they are contrary to governmental policy objectives, thus opening the way to government intervention. One observes a contradiction between a neoliberal rhetoric that favours market regulation and the reduction of state intervention and a de facto increase of intervention by the state.

In the UK, government intervention is more systematic; in the 'weak state' of Portugal government intrusion to change the rules of the game is more arbitrary and occurred only after a crisis situation was declared.

One might say that the new relationship between the HEIs and the government is portrayed by the "roundabout model" (Jongbloed 2004) but with an increasing number of (government) traffic lights inside the roundabout restricting the routes. This is consistent with the idea that an effective delegation of 'public-interest decision-making' authority to institutions requires "an affirmative desire to interpret and serve the public good, the will to hold institutional self-interest at bay, and the financial strength to balance intrinsic values with market forces" (Massy 2004b, p. 33). Unchecked behaviour of institutions however, especially under conditions of strong competition and financial stringency, may not correspond to the best public interest, which makes a strong case for government intervention.

Therefore, one has to infer that it is very unlikely that Prometheus will be unchained in the visible future. The modern Zeus wants to give knowledge to the mortals - even if his idea is that they will repay this gift with their labour under less stable contracting conditions - and he is afraid that an unchained Prometheus will place his own interest above that of the humans he used to protect, thus interfering with God's plans. This is a post-modern version of Greek mythology where Prometheus, the former mythic friend of humanity becomes the bad guy that the eagle (the state) will continue tormenting, in some cases in a more sporadic but also more savage way. 


\section{References}

AHESG (2004). Fair Admissions to Higher Education: recommendations for good practice http://www.admissions-review.org.uk/downloads/finalreport.pdf.

Amaral, A. and Teixeira, P. (1999). Previsão da evolução do número de alunos e do financiamento. Coimbra: Fundação das Universidades Portuguesas.

Amaral, A. and Teixeira, P. (2000). 'The rise and fall of the private sector in Portuguese higher education?', Higher Education Policy, 13, 3, 245-266.

Clarke, C. (2003). Statement to the Commons. http://education.guardian.co.uk/specialreports/tuitionfees/story/0,,88 0051,00.html.

Correia, F., Amaral, A. and Magalhães, A. (2002). Diversificação e diversidade dos sistemas de ensino superior. O caso Português. Lisboa: CNE.

Crown Copyright (2004). Higher Education Act.

http://www.opsi.gov.uk/ACTS/acts2004/20040008.htm.

Department for Education and Skills (Dfes) (2003a). The future of higher education. Norwich: HMSO.

Department for Education and Skills (Dfes) (2003b). Widening Participation in Higher Education.

http://www.dfes.gov.uk/hegateway/hereform/whitepaperconsultation /index.cfm.

Department for Education and Skills (Dfes) (2004a). Commentary on responses received on the Higher Education White Paper and Paper on Widening Participation.

http://www.dfes.gov.uk/hegateway/uploads/FResponsesHEWP.pdf.

Department for Education and Skills (Dfes) (2004b). Consultation Report, Analysis of responses to the consultation paper on proposed new criteria for awarding powers and university title.

http://www.dfes.gov.uk/consultations/conresults.cfm?consultationid $=1226$.

Department for Education and Skills (Dfes) (2004c). 'Renewable Degree Awarding Powers'. Discussion Paper.

http:/www.dfes.gov.uk/hegateway/uploads/Renewable\%20Degree\% 20Awarding\%20Powers\%20Discussion\%20Paper.pdf. 
Department for Education and Skills (Dfes) (2004d). 'Consultation Report. Analysis of responses to the consultation paper on renewable degree awarding powers'. Discussion paper.

http://www.dfes.gov.uk/consultations/downloadableDocs/Renewable $\%$ 20Degree\%20Awarding\%20Powers\%20-\%20responses 1.doc.

Department for Education and Skills (Dfes) (2004e). 'Applications for the taught degree-awarding powers, research degree-awarding powers and university title'. Guidance for applicant organisations in England and Wales.

http://www.qaa.ac.uk/reviews/dap/CriteriaGuidance.asp.

Dill, D., Teixeira, P., Jongbloed, B. and A. Amaral (2004). 'Conclusion', in Teixeira, P., Jongbloed, B., Dill, D. and Amaral, A. (eds.), Markets in Higher Education - Rhetoric or reality? Amsterdam: Kluwer Academic Publishers, pp. 327-352.

Habermas, J. (1987). 'The Idea of the University - Learning Processes', New German Critique, 41, 3-22,

JM Consulting (2004). 'The costs of widening paticipation in higher education'. A report for HEFCE, UUK and SCOP. http://www.hefce.ac.uk/pubs/rdreports/2004/.

Jongbloed, B. (2004). 'Regulation and Competition in Higher Education', in Teixeira, P., Jongbloed, B., Dill, D. and Amaral, A. (eds.), Markets in Higher Education - Rhetoric or reality? Amsterdam: Kluwer Academic Publishers, pp. 87-111.

Kraak, A. (2001). 'Policy Ambiguity and Slippage: Higher Education Under the New State, 1994-2001'. CHET Commissioned Paper, Pretoria: CHET. http://www.chet.org.za/papers/Kraak.doc.

Lindsay, G. and Rogers, T. (1998). 'Market orientation in the UK higher education sector: the influence of the education reform process 1979-1993', Quality in Higher Education, 4, 2, 159-171.

Massy, W.F. (2004a). 'Markets in Higher Education. Do they promote internal efficiency?', in Teixeira, P., Jongbloed, B., Dill, D. and Amaral, A. (eds.), Markets in Higher Education - Rhetoric or reality? Amsterdam: Kluwer Academic Publishers, pp. 13-35.

Massy, W.F. (2004b). 'Collegium Economicum: Why Institutions Do What They Do?' Change, 36, 4, 26-35.

Neave, G. (1995). 'The Stirring of the Prince and the Silence of the Lambs: The Changing Assumptions Beneath Higher Education Policy, Reform, and Society', in Dill, D. and Sporn, B. (eds.), Emerging Patterns of Social Demand and University Reform: Through a Glass Darkly. Oxford: Pergamon Press, pp. 54-71. 
Neave, G. and van Vught, F. (1991). Prometheus Bound; the Changing Relationship between Government and Higher Education in Western Europe. Oxford: Pergamon Press.

PA Consulting Group (2004). 'Survival of the Fittest'. A survey of the leadership of strategic change in higher education, London.

Portugal (1975). Programa do V Governo Provisório. Lisboa: Imprensa Nacional Casa da Moeda.

Shattock, M. (2001). 'The Governance of Universities in the PostDearing Era: Rebalancing the modern concept of university governance'. Paper delivered at the UK Society for research in Higer Education Seminar, London.

Scott, P. (1995). The Meanings of Mass Higher Education. Buckingham: SHRE and Open University Press.

Sousa Franco, A. (1994). 'A Liberdade de Aprender e de Ensinar no Âmbito das Liberdades Fundamentais: Fundamentação da Liberdade de Ensino', in Carneiro, R. (ed.), Ensino Livre: Uma Fronteira da Hegemonia Estatal. Lisboa: Asa Edições.

Tapper, T. and Salter, B. (2004). 'Understanding Governance and Policy Change in British Higher Education', Oxford CHEPS Occasional Paper, 11, Oxford.

http://oxcheps.new.ox.ac.uk/MainSite\%20pages/papers.html.

Teixeira, P., Amaral, A. and Rosa, M.J. (2003). 'Mediating the Economic Pulses - The international connection in Portuguese Higher Education', Higher Education Quarterly, 57, 2, 181-203.

Teixeira, P. and Amaral, A. (2001). 'Private Higher Education and Diversity: An exploratory survey', Higher Education Quarterly, 55, 4, 359-395.

Teixeira, P., Rosa, M.J. and Amaral A. (2004). 'Is there a higher education market in Portugal?', in Teixeira, P., Jongbloed, B., Dill, D. and Amaral, A. (eds.), Markets in Higher Education - Rhetoric or reality? Dordrecht: Kluwer Academic Publishers, pp. 291-310.

Trow, M. (1996). 'Trust, Markets and Accountability in Higher Education: a Comparative Perspective', Higher Education Policy, 9, 4, 309-324.

van Vught, F. (1989). Governmental Strategies and Innovation in Higher Education. Londen: Jessica Kingsley.

van Vught, F. (1996). 'A Cybernetic Higher Education Institution'. Presented at the annual CHER conference, Turku.

World Bank (1977). 'World Bank Project Identification Mission Report - Republic of Portugal', manuscript. Washington: World Bank.

World Bank (1989). 'Republic of Portugal - Higher Education, A Program for Reform', manuscript. Washington: World Bank. 